\title{
ON THE MATTER OF THE STATE OF THE IMMOVABLE CULTURAL HERITAGE OF THE CITY OF VARNA
}

\author{
Milena Ivanova \\ University of Economics Varna, \\ 77, Knyaz Boris I Blvd, \\ 9002 Varna, Bulgaria \\ e-mail: milena_ivanowa@ue-varna.bg
}

\begin{abstract}
The immovable cultural heritage provides important benefits to the community, which to a significant extent determines the specific look and spirit of a location. It is a long-term asset, a non-renewable resource and a factor that influences the development of tourism. The goal the author of this article has set herself is to present the state of the immovable cultural heritage of the city of Varna.

Keywords: city of Varna, cultural heritage, state of the immovable cultural heritage.
\end{abstract}

\section{INTRODUCTION}

The Information Register of the Immovable Cultural Heritage of the city of Varna, the first of its kind in Bulgaria, was established in 2020 [1]. The register is based on a public procurement study of Varna Municipality conducted in 2015 for the purpose of updating the overall list of the immovable cultural heritage of the city. The register is available online and provides a free-to-search-and-view graphic, documentary, historical and geographical information about the buildings of cultural significance in Varna. The register is the work of a team of specialists consisting of Arch. I. Racheva, D. Eftimov, D. Penev and Arch. Vl. Rachev.

The goal of the author of this article is to present the state of the immovable cultural heritage of the city of Varna.

DOI: 10.7546/EngSci.LVII.20.04.06 


\section{STATE OF THE IMMOVABLE CULTURAL HERITAGE OF THE CITY OF VARNA}

The Bulgarian legislation considers the cultural heritage in two ways - as tangible and intangible heritage. The tangible heritage in its turn is considered movable and immovable. For the purpose of this article we will refer to the definition of immovable cultural heritage given in the Cultural Heritage Act, namely: "The immovable cultural heritage includes cultural values permanently fixed to the ground, including under water, as well as their adjacent environment" [2]. The immovable cultural heritage is a resource that should be protected and managed efficiently. By "protection of cultural heritage" we shall mean a systematic search, study, identification, documentation, registration, conservation, restoration and adaptation process [3]. This view on the essence of the term "protection of cultural heritage" also covers all actions undertaken for its documentation and registration. In other words, we cannot have our immovable cultural heritage protected if it is not properly registered and documented. This vision is also embedded in Art. 59 of the Immovable Cultural Heritage Act. It says that the local authorities are under the obligation to keep regional archives of the immovable cultural properties, but it fails to specify what exactly these archives must contain.

Information about the number and type of the immovable cultural objects in the city of Varna is given in Table 1.

Table 1. Number of the immovable cultural objects in the city of Varna

\begin{tabular}{|l|l|l|}
\hline $\begin{array}{l}\text { Buildings having the status of archi- } \\
\text { tectural and construction/ histori- } \\
\text { cal/art/landscape significance }\end{array}$ & $\begin{array}{l}\text { Archeological } \\
\text { sites }\end{array}$ & $\begin{array}{l}\text { Buildings having no spe- } \\
\text { cific status - proposed for } \\
\text { being declared again }\end{array}$ \\
\hline 510 & 105 & 150 \\
\hline
\end{tabular}

Sources: https://www.varnaheritage.com

The data in the table point to the fact that there is a significant number of immovable cultural objects in Varna. What is really impressive is the large number of objects which have no specific status but are proposed for being redeclared. Important and fast measures should be taken to categorize them as soon as reasonably possible. The number of archeological sites is also significant. The reason for the large number of archeological sites should be sought in the rich historical past of the city of Varna. The city has a millennialong history, and one of the proofs of this is the Varna Chalcolithic necropolis discovered near Varna Lake in 1972. The site is one of the most important monuments not only for Varna and for Bulgaria, but also for Europe. Until 
relatively recently, the necropolis was abandoned and neglected. However, a positive moment is the establishment of the Varna Necropolis Association the goal of which is to restore the excavations (about $1 / 4$ of the necropolis has not been studied), and tune the place into an attractive tourist destination. World practice has shown that the protection of architectural monuments discovered by archaeologists requires three to twenty times more funds than the excavations themselves. However, there are no provisions in the legislation as to who is responsible for making these funds available and invested [4].

According to their spatial arrangement the immovable cultural objects in the city are divided into single, group and ensemble (See Table 2):

Table 2. Spatial arrangement of the immovable cultural objects in Varna

\begin{tabular}{|c|c|}
\hline Status & Number \\
\hline Single & 506 \\
\hline Group & 4 \\
\hline Ensemble & 3 \\
\hline
\end{tabular}

Sources: https://www.varnaheritage.com

This indicator is important when owners of buildings of cultural significance apply for funding under immovable cultural heritage protection programs. For instance, in 2020 a Cultural Heritage Program was launched at the Sofia Municipality, the goal of which was to support the protection of the immovable cultural heritage within the territory of the municipality by helping owners of immovable cultural property to do and perform activities for the protection, restoration, conservation and their socialization [5]. A methodology for a complex evaluation of the applications under the program has also been developed. The maximum amount of points each application may earn by the set indicators is 100 in total. One of the indicators (K1) that is used in the formation of the comprehensive assessment is the spatial arrangement of the site. According to this methodology, if the building is a single immovable cultural property and falls into a group of immovable cultural properties, it earns 15 points. If the building is a single immovable cultural property but does not fall into a group of immovable cultural properties, it earns 10 points. If the building is not a single immovable cultural property, but is part of a group of immovable cultural properties, it earns 5 points [6]. A similar methodology can be developed by the municipality of Varna if a funding is made available to support the owners of buildings of cultural significance. 
Information on the technical condition of the immovable cultural objects in Varna is given in Table 3:

Table 3. Technical condition of the immovable cultural objects in Varna

\begin{tabular}{|c|c|c|c|c|c|}
\hline Good & Satisfactory & $\begin{array}{c}\text { Demolished } \\
\text { building }\end{array}$ & Poor & $\begin{array}{c}\text { Buildings } \\
\text { at risk }\end{array}$ & $\begin{array}{c}\text { In a process } \\
\text { of restoration }\end{array}$ \\
\hline 208 & 195 & 3 & 95 & 10 & 3 \\
\hline
\end{tabular}

Sources: https://www.varnaheritage.com

The data in the table point to the fact that only $40 \%$ of the buildings are in good condition. This, however, makes one wonder is not the good condition of the building attained at the expense of its authenticity. Buildings of cultural significance can be seen on many streets in Varna that look all right at a casual glance, but for their repair or renovation were employed materials which to a significant extent move the building away from its original architecture and its original appearance. A typical example of this is the building of the former Imperial Hotel on Frederic Chopin Street. Preservation of the good condition of the buildings of cultural significance, but moving away from their authentic appearance, is also seen in their renovation. In this case there is an improved energy performance of the buildings, but deleted or remodeled frontal ornaments. These practices are good example of the so called "replacement technology", where original examples of urban architecture from the late $19^{\text {th }}$ and the early $20^{\text {th }}$ century are replaced by imitations, poor copies of the original or anachronistic stylistic decorations which are not aligned with the times. This phenomenon known as "replacement technology" was given a detailed description by Arch. St. Vekov in "What are the current trends in the Immovable Cultural Heritage of Varna" [7]. More than half of the buildings of cultural significance in Varna need protection measures. If no such measures are taken these buildings are placed under the serious threat of sharing the same destiny as The Pink House, The Potato House, the building of the French College St. Michael, the French College Saint Andre and others (the said buildings have already been demolished, and do not exist).

The categories of the buildings of cultural significance in Varna are given in Table 4.

There are no sites within the territory of the city having been identified with a world significance. No such sites have even been listed among the applications for inclusion into the UNESCO World Heritage List. The buildings of cultural significance which have been identified with national significance are the Roman Thermae, the Old Bulgarian Fortification Wall Asparuhov Val, 
Table 4. Category of the buildings of cultural significance

\begin{tabular}{|c|c|}
\hline Category & Number \\
\hline Identified with national significance & 6 \\
\hline Identified with local significance & 13 \\
\hline Identified with ensemble significance & 54 \\
\hline With no status & 437 \\
\hline
\end{tabular}

Sources: https://www.varnaheritage.com

the Early Christian Basilica Dhanavar-tepe, Aladzha Monastery, the Thracian Tomb in the Vladislav Varnenchik Park and the Central Entrance of the Sea Garden - the propylaea [8]. The buildings having no status are at the top of the list. To accord an immovable cultural property status to a site means to determine its classification, category and protection regimes based on a final assessment [9]. Designating a status to a declared site is important so that the site could be protected. According to Art. 13 of Regulation No. 5 on the reporting of the immovable cultural monuments, the sites reported are only temporarily protected as immovable cultural monuments until their cultural and historical value and public significance are finally established [10].

The breakdown of the buildings of cultural significance by form of ownership is as follows (see Table 5).

Table 5. Breakdown of the buildings of cultural significance by form of ownership

\begin{tabular}{|c|c|}
\hline Ownership & Number \\
\hline Exclusively state-owned & 1 \\
\hline State public & 19 \\
\hline State private & 11 \\
\hline Municipal public & 15 \\
\hline Municipal private & 71 \\
\hline Private & 338 \\
\hline Co-owned & 55 \\
\hline
\end{tabular}

Sources: https://www.varnaheritage.com

The data in the table show that about $66 \%$ of the buildings of cultural significance are privately owned. Article 71 of the Cultural Heritage Act states that the owners, concession operators and users of immovable cultural properties are obliged to take all necessary measures to protect, preserve and keep them in good condition. This requires a significant amount of funds - more 
than the funds needed to maintain and repair a building with no cultural value. The owners of these buildings often do not have the funds needed to maintain the good condition of these buildings. No incentives are offered to the owners, on both national and local level, so that they could engage themselves in their repair, maintenance and renovation. Apart from that, each activity performed on an immovable cultural object is associated with complex and time-consuming administrative and bureaucratic procedures. In certain circumstance this time has a disastrous impact on the immovable cultural object. There are cases in practice where a building of cultural significance was demolished days before it was accorded a status. The common attitude is that owning an immovable cultural heritage creates a lot of inconveniences and restrictions which make these people or organizations leave the cultural heritage to fall to ruin [3]. The owners of buildings of cultural significance are exempt from real estate tax when the building is not used for commercial purposes. This, however, is extremely insufficient given the significant costs the maintenance of these sites requires.

According to their function the buildings of cultural significance are divided as follows (See Table 6).

Table 6. Function of the buildings of cultural significance

\begin{tabular}{|c|c|}
\hline Function & Number \\
\hline Residential buildings & 376 \\
\hline Training buildings & 6 \\
\hline Religious buildings & 16 \\
\hline Industrial buildings & 2 \\
\hline Special-purpose & 18 \\
\hline Public/administrative buildings & 92 \\
\hline
\end{tabular}

Sources: https://www.varnaheritage.com

The above data indicate that the residential homes take up the largest share of immovable cultural property, followed by public/administrative buildings. The good thing here is that all six training buildings of cultural significance are in good condition. Among them is the building of the University of Economics Varna, built in 1914. In 2015 the university building was awarded the Building of the Year prize in the Cultural monuments, museums, temples category. The industrial buildings of cultural significance are only two: the Diesel Power Plant and the Hristo Botev Factory. Both buildings are located on Devnya Street. Unfortunately, the Hristo Botev Factory falls into the Buildings at risk category and if no measures are undertaken to protect it, this building 
- the work of Architect Dabko Dabkov, is much more likely to be destroyed (self-destroyed).

The foregoing information about the state of the immovable cultural heritage of the city of Varna allows us to summarize the following:

1. Varna is a city with a remarkable resource of immovable cultural objects. The reasons for this are the millennia-long history of the city - in Varna and in its neighborhood are found material traces of the primeval history, the Antiquity, the Middle Ages, the Revival and the Modern Times. Artists such as Dabko Dabkov, Herman Meyer, Stefan Venedikt Popov, Nikola Lazarov, and others, have left their marks in the city.

2 . The register of the immovable cultural heritage of the city of Varna was only established in 2020. Before that there was a register that was established and updated in 1987 [11]. This makes it very difficult to examine into the dynamics of the number of immovable cultural properties over the last few years.

3. On a local level it has been recognized how important the immovable cultural heritage is as a contributing factor for the development of the cultural tourism and for preservation of the cultural identity. Immovable Cultural Heritage Department has been established to the Architecture, Urban Planning and Spatial Planning Directorate.

4. What speaks to the fact that the local authorities have realized the significance of the immovable cultural heritage is the establishment of the new register in response to the public procurement order on Identification/upgrading and proposal for reporting of the immovable cultural properties within the territory of Varna Municipality.

5. What is still lacking despite the fact that an immovable cultural heritage register has been established is a regulation to determine the rules for monitoring, control and assessment of the condition of the immovable cultural objects in the city. Such regulations are necessary because the monitoring of the immovable cultural property within the provisions of the national legislation is incomplete and partially regulated.

6. Inefficient coordination and interaction between the municipalities and the Ministry of Culture in performing the procedures for administration of control and application of protection measures with respect to the immovable cultural properties, as a result of which there is an insufficient operation of the national cultural heritage protection policy [12]. 


\section{CONCLUSION}

In conclusion, the following recommendations can be formed based on the study:

1. Establishment and maintenance of an e-folder for each building of cultural significance for the purpose of making their management and protection easier.

2. Accurate maintenance of the register of the immovable cultural heritage, and if possible - its addition.

3. Increasing the capacity of the municipal administration that deals with the problems of the immovable cultural heritage. At present, the Immovable Cultural Heritage Department at Varna Municipality employs seven specialists qualified in architecture, engineering and law, and no specialist qualified in economics. There are also no certified appraisers of immovable cultural objects.

4. Improvement of the coordination between the local structures engaged in the protection of the immovable cultural objects and the Ministry of Culture.

5. Assessment of the economic feasibility of the function of the immovable cultural objects by determining how much costs it would take to maintain it and what are the potentials to bring in returns on a market basis. This requires some analysis and evaluation of the various alternatives for the operation of the object - income from visitations, inclusion in cultural events, manufacturing of souvenirs and multimedia products for commercial purposes, allowing commercial activities on the object, etc. [13].

6. Establishment of a territorial division of the National Institute for Protection of the Immovable Cultural Heritage (NIPICH) for the purpose of ensuring a better performance by the institute of its functions and goals, faster administrative services to individuals and businesses and better communication between NIPICH and the local authorities.

In conclusion, we must note that this study is not exhaustive. The opportunity to trace through the dynamics of each indicator will help making broader assertions as to where the immovable cultural heritage of the city of Varna is heading.

\section{REFERENCES}

[1] Information Register of the Immovable Cultural Heritage of Varna (online) (202010-10), Available at: https://www.varnaheritage.com/.

[2] Cultural Heritage Act, Published in SG No.19/13 March (2009).

Engineering Sciences, LVII, 2020, No. 4 
[3] Functional analysis of the sector policy in the area of the protection and presentation of the immovable cultural heritage (online), (202010-10), Available at: http://www.strategy.bg/Publications/View.aspx?lang=bgBG\&categoryId $=\& I d=268 \& y=\& m=$.

[4] P. Balabanov, Law, society, monuments, The cultural heritage in the modern city, New Bulgarian University, Sofia (2009) 77-78, ISBN 978-954-535-645-2.

[5] Sofia Municipality (2020) (online), (2020-10-10), Available at: https://www.sofiaagk.com/Pages/Render/1018.

[6] Methods for a comprehensive assessment of the applications under the Cultural Heritage Program of Sofia Municipality (2020) (online), (202010-10), Available at: https://www.sofia-agk.com/FileBrowser/File?path= esoft.portal\%2FKULTURNO\%20NASLEDSTVO1\%2F2_\%D0\%9C\%D0\%B5\%D1 $\% 82 \%$ D0\%BE\%D0\%B4\%D0\%B8\%D0\%BA\%D0\%B0\%20\%D0\%B7\%D0\%B0\%20 \%D0\%BE\%D1\%86\%D0\%B5\%D0\%BD\%D0\%BA\%D0\%B0.pdf.

[7] St. Vekov, Where the immovable cultural heritage of Varna is heading, in: Proceedings of the Union of Scientists, Varna, 2014, pp. 144-154.

[8] Ministry of Culture (online), (2020-10-10), Available at: http://mc.government.bg/ images/NPK/VARNA.pdf).

[9] Regulation No. 3 of 10 July 2019 on the order for identification, reporting, giving a status and determination of the category of the immovable cultural properties, for the access to the circumstances subject to entry into the national public register of the immovable cultural properties, Published in SG No. 57/19 March (2019).

[10] Regulation No. 5/14 May 1998 on the reporting of the immovable cultural monuments, Published in SG No. 60/27 May (1998).

[11] Register of the immovable cultural properties in Varna dated 1987 (online), (2020-10-10), Available at: https://www.varna.bg/bg/258.

[12] Audit Report No. 0300100418 for an audit of the persomance of protection and maintenance of architectural heritage sites in urban environment for the period 1 January 2015-30 June 2018 (2018), 89-90.

[13] M. Krastev, Opportunities for assessment of the cultural heritage of Sofia as a sustainable urban development resource, Space-society-economics, Sofia (2019) $321-322$.

Received December 06, 2020 